\title{
Development of the Vestibular System
}

\author{
C.H. Lai Y.S. Chan \\ Department of Physiology, Faculty of Medicine, The University of Hong Kong, Hong Kong, China
}

\section{Key Words}

Vestibular system - Prenatal development · Postnatal development · Maturation - Vertebrates

\begin{abstract}
This review mainly focuses on the development of the vestibular system in humans and other mammals, but reference is made to anurans and other species where applicable. In the first section, the steps involved in the development of undifferentiated cells into mature vestibular receptors are analysed. Available data indicate that in humans, maturation of the vestibular receptor and its afferent innervations involves a similar sequence of events as in other mammalian species. In the second section, morphological and physiological aspects of the maturation of the central vestibular system are presented. Undifferentiated neuron precursors have been identified in specific segregrated domains of the hindbrain neural tube, and these can develop into secondary vestibular neurons with unique properties. Several neuronal populations in the vestibulospinal and vestibulo-ocular pathways have been found to correlate with rhombomeric domains at early embryonic stages. In rodents, the vestibular system continues to develop postnatally in terms of morphology and function until it achieves its final form. The postnatal changes in the properties of vestibular nuclear neurons are chronologically matched with structural changes and serve to prime the development of vestibular-induced reflexes.
\end{abstract}

Copyright $@ 2002$ S. Karger AG, Basel

\begin{tabular}{ll}
\hline KARGER & @ 2002 S. Karger AG, Basel \\
Fax +41 61 306 1234-8522/02/0012-0061\$18.50/0 \\
$\begin{array}{l}\text { E-Mail karger@karger.ch } \\
\text { www.karger.com }\end{array}$ & $\begin{array}{l}\text { Accessible online at: } \\
\text { www.karger.com/journals/neb }\end{array}$
\end{tabular}

The time course of the maturation of hair cells and their afferent innervation patterns in the vestibular system has been fully documented in histological and ultrastructural studies in a number of animal species, such as rats [1, 2] and mice [3-9], as well as in humans [10]. Comparison of different maturational events in humans and other animals is of particular interest. Through these correlations, it is possible to extrapolate from experimental results in animals to predict what may occur in the human vestibular system.

\section{Development of the Peripheral Vestibular System}

\section{Ontogeny of Vestibular Hair Cells}

In humans, the sensory epithelium remains undifferentiated until week 7 of gestation $[9,10]$. At 7 weeks, nascent hair bundles can be seen in the central zone of the immature sensory epithelium, indicating that a few hair cells have begun their differentiation. The emerging hair bundle is formed by a group of cilia of the same length and has no precise polarity, i.e. the kinocilium cannot be distinguished from the stereocilia [11]. This arrangement is characteristic of what has been described as the initial stage of formation of the hair tuft in the mouse [12]. Most of the sensory epithelium in mouse vestibular organs is composed of a pseudo-stratification of undifferentiated cells at E14 [12, 13]. From embryonic day 14 (E14) to postnatal day $2(\mathrm{P} 2)$, terminal mitoses of hair cells and

\footnotetext{
Prof. Y.S. Chan

Department of Physiology, Faculty of Medicine

The University of Hong Kong, 21 Sassoon Road

Hong Kong (China)

Tel. +852 28199263, Fax +852 28559730, E-Mail yschan@hkucc.hku.hk
} 
supporting cells occur, with a peak at E16 [14]. By E16, immature hair cells with short stereocilia are evident [6]. Morphological differentiation into type I and type II hair cells starts at E19 in the mouse [3], while this developmental stage appears in the 11th to 13 th week of gestation in humans [11]. Type I and type II hair cells have different cell shapes $[4,15]$, hair bundle geometry $[16,17]$ and voltage-gated conductance [18-21]. In the mouse utricle, type I hair cells, but not type II hair cells, are characterized by a large $\mathrm{K}^{+}$conductance $\left(\mathrm{g}_{\mathrm{K}, \mathrm{L}}\right)$ that is activated at unusually negative voltages $[8,21]$. This conductance is absent at birth, but begins to be expressed at P4 [4].

Using autoradiography to trace the chronology of the normal development of rat vestibular receptors, Sans and Chat [22] demonstrated that maturation of the hair cells is more precocious (1) at the centre than at the periphery of the utricular maculae, and (2) at the apex than at the base of the cristae. In the embryonic stage, the maturation gradient of hair cells as described by terminal mitoses [22], ciliogenesis [5] and synaptogenesis [13] is also consistent with the developmental appearance of neuron-specific enolase and calbindin-D28K (protein markers that respectively indicate differentiation and synaptic activity of neurons) in the vestibular epithelium of the mouse [23] and human [24]. In the mouse [25], these changes parallel the morphological sequence of maturation from apex to base in the cristae and centre to periphery in the maculae $[24,26]$. In summary, the maturation of the vestibular receptor, which is mature before birth in humans [11], involves a similar sequence as in other mammalian species.

\section{Innervation of Vestibular Hair Cells}

In the mouse, afferent and efferent nerve endings at the vestibular receptors are first identified at E17 and E18, respectively [13, 27]. Numerous unmyelinated afferent fibres contact hair cells at their base, forming flat and vesiculated terminals. These early hair cell-afferent fibre contacts develop into synapses characterized by the presence of synaptic bodies within the hair cells $[9,11]$. An increase in the number of synaptic bodies at the beginning of synaptogenesis has also been observed in the human fetus between the 9th and 10th week [11]. In the mouse, partial calyces endings are seen as early as E18 [27]. Full calyces endings are first present in significant numbers some days after birth in the mouse [7, 28] and at the 20th week of gestation in humans. In the mouse, myelination of the peripheral afferent fibres starts on the day of birth, well after the first observation of synapses in the vestibular epithelium on E16 [13]. This process appears to be the final maturational event in the peripheral vestibular system and is not yet complete by P7. The exact time of maturation, however, remains to be ascertained.

In the late embryonic stages in the mouse, more efferent endings are found to be making contact either directly on the hair cells or on nerve calyces. The amount of efferent endings, however, has not yet reached its adult abundance at this stage [11,29]. Immunohistochemical and confocal microscopic results have demonstrated that the efferent innervation pattern in rats continues to develop between P9 and P12 [29, 30]. In this postnatal period, however, animals exposed to a microgravity environment showed no plastic changes in the organization of the vestibular efferent network in the utricle [31]. In adult animals, it has been proposed that the vestibular efferent innervations provide modulatory control of signal transduction between the hair cells and the afferents [30, 3234]. Efferent activation in the toadfish was found to result in an elevation of afferent activity such that the rectified response to acceleration became bidirectionally responsive without a change in response sensitivity [32]. A decrease in the number of clipped otolith neurons with age has also been attributed to the maturation of the efferent system [35], which only fully develops in the third postnatal week [36]. Nonetheless, the contribution of the efferent system to the postnatal maturation of vestibular function awaits further study.

\section{Morphophysiological Correlations}

Morphophysiological experiments carried out with intracellular injections of horseradish peroxidase in adult monkeys indicated that the response characteristics of the functionally identified afferent axons closely correlate with the location of their terminal field in the vestibular epithelium [37, 38]. For example, calyx units, which contact only type I vestibular hair cells in the central zone of the epithelium, were found to be discharging irregularly [38]. However, dimorphic units, which innervate both type I and II hair cells, exhibited different discharge regularities depending on their location on the macula. More irregularly discharging afferents were found to innervate the striola region than in the peripheral extrastriola region of the utricular macula [38]. In response to sinusoidal head rotations, calyx units and irregularly discharging dimorphic units showed larger phase leads and, hence, more phasic response dynamics than regularly discharging dimorphic units. Such differences are related to regional variations in the transduction mechanism of hair cells [38]. The results suggest that the response characteristics of functionally identified afferent axons are largely 
determined by the status of vestibular hair cells and their innervation pattern.

The correlation between the morphology of afferent terminals and their spontaneous activity has also been studied in the mouse during the first postnatal week [39]. Development of the innervation pattern was characterized by labelling the afferents with intracellular injections of horseradish peroxidase performed between E17 and P10 [3]. This developmental stage corresponds to middle and late synaptogenesis between vestibular hair cells and primary afferent nerve terminals $[10,13]$. In the mouse, the initial stages of synaptogenesis take place during the embryonic period $[6,10,13]$ and seem to coincide with the end of terminal mitosis in hair cells [14]. On day 20 of gestation, the first endings differentiated into boutons or calyces [3]. The afferent innervation on the hair cells developed rapidly during the first 5 postnatal days. The proportions of the three types of units (i.e. calyx, bouton and dimorphic units) on P10 were comparable to those described in the adult chinchilla [40]. These results correlate with the physiological maturation of both canal-related and otolith-related vestibular afferents, as detailed in the following section.

\section{Functional Development of Primary Vestibular \\ Neurons}

Recording of primary vestibular neuronal activity in the course of postnatal development has been performed mainly in vivo in the rat [41-44] and the cat [45], and in vitro in the mouse $[39,46]$. In early postnatal life, some canal afferent neurons in the rat exhibited slow, irregular and near-zero spontaneous activity at rest, punctuated by random, unpredictable bursts of spikes [42, 43]. Increases in the mean resting discharge rate as well as in the proportion of canal regular units have been observed in the kitten [45] and in the rat $[42,43]$. In the rat, regular activities appeared on $\mathrm{P} 4$, and the mean resting rate continued to increase steadily, reaching adult levels in the third postnatal week. In adult rats, about $32 \%$ of primary canal neurons fired regularly, and the mean resting discharge rate of these regular neurons was significantly higher than that of irregular neurons [42]. During postnatal development, there was also an increase in the response sensitivity of the canal afferent system and a progressive change in the response dynamics. With the use of long-duration constant angular acceleration, Curthoys [43] showed that the canal system was not very sensitive at birth, but its sensitivity increased rapidly after birth and became close to that of adults by $\mathrm{P} 4$. In the first postnatal week, primary canal neurons also showed a rapid increase in response gain during sinusoidal rotations and a slower decrease in phase lag [43]. Since the dynamic characteristics are related to the transduction mechanism of hair cells [37, 38], the phase-lag response pattern observed in neonatal rats [43] is correlated with the development of the hair cells and their afferent innervation patterns [46].

More recently, the functional properties of otolith afferents have also been examined in young and adult rats [47]. In early postnatal life (before P12), otolith afferents displayed a lower spontaneous firing rate and a more irregular discharge pattern than in older rats. Some vestibular afferents also showed a rhythmic bursting firing pattern with almost equal interspike intervals within bursts and interburst intervals [47]. Such a burst firing pattern, however, was not observed after P14. In contrast to reports of canal afferents [42, 43], no regular afferents were found in the first postnatal week. Regular activities were only observed in otolith afferents on P9, 5 days after the first appearance of regular canal afferents [42]. Reasons for the late appearance of regular activities in the otolith system, however, are still unclear. Further experiments are required to delineate whether there exists a differential maturation profile between the peripheral canal system and the otolith system.

\section{Development of the Central Vestibular System}

\section{Afferent Projection to the Vestibular Nuclei}

In mammals, vestibular afferents that innervate the vestibular hair cells form part of the eighth cranial nerve, which enters the brain stem at the level of the inferior cerebellar peduncle and terminates primarily within the vestibular nuclei. In the classical description of the vestibular system, vestibular neurons in the hindbrain are grouped into nuclei on the basis of cytoarchitectonic features such as cell size, shape and distribution [48, 49]. The vestibular nuclear complex can be subdivided into four main nuclei, namely the superior, lateral, medial and descending or spinal [48]. Vestibular nerves enter the vestibular nuclear complex at the level of the lateral vestibular nucleus [50], where they typically bifurcate into a descending tract that branches within the medial and descending vestibular nuclei and an ascending tract which terminates in the superior vestibular nucleus as well as sending projections to the cerebellum (primarily the uvula and nodulus) [see ref. 51 for a review, 52, 53].

During development in all vertebrates, the embryonic hindbrain neuroepithelium is organized at the gross morphological level as a series of segments known as rhom- 
bomeres [54-56]. In larval frogs, vestibular afferent fibres enter the brain stem at rhombomere 4, split up into ascending and descending fibre bundles and terminate in the dorsal hindbrain between rhombomere 1 and rhombomere 8 in a region corresponding to the vestibular nuclear complex of adult frogs $[57,58]$. Of the four main vestibular nuclei, the superior vestibular nucleus appears to derive from larval rhombomere $1 / 2$, the lateral vestibular nucleus from rhombomere $3 / 4$ and the major portions of medial and descending vestibular nuclei from rhombomeres 5-8 [59].

Anatomical studies have demonstrated the spatial and temporal sequence of proliferation gradients in the vestibular nuclear complex [60] and the temporal sequence of dendritic and somatic growth and synaptic formation within the lateral vestibular nucleus of the rat $[61,62]$ and humans [63]. Altman and Bayer [60] reported that the differentiation of neurons within the vestibular nuclei in rats occurs between E11 and E15 and follows latero-medial and rostro-caudal internuclear gradients. Peak production time is E12 in the lateral vestibular nucleus, E13 in the superior nucleus, E13-E14 in the descending (or spinal) nucleus and E14 in the medial nucleus [60]. Thus, the development of these nuclei seems to be linked to the relative importance of their roles in the early embryo. The lateral and descending vestibular nuclei, involved in postural stabilization from birth, mature before the superior and medial nuclei, which are involved in gaze stabilization, which appears 2 weeks later [60]. In humans, although neurons in the lateral vestibular nucleus have been distinguished from glia after 16 weeks of gestation [63], the pattern of differentiation of neurons within the vestibular nuclei is still unclear.

\section{Functional Development of Central Vestibular Neurons}

The postnatal development of spontaneously active medial vestibular neurons, which can be distinguished by after-hyperpolarizations into type A and type $\mathrm{B}$, has been characterized in mouse brain slices [64]. Without inputs from the vestibular nerve, these medial vestibular neurons displayed intrinsic pacemaker-like membrane conductances that generated resting activity [65-68]. At P5, both the type $\mathrm{A}$ and the type $\mathrm{B}$ neurons were found to exhibit immature forms of action potential. During postnatal development, the single after-hyperpolarization in type A neurons gradually became deeper, and the early fast after-hyperpolarization appeared in type B neurons at P15 [66]. In addition, the apamin-sensitive slow afterhyperpolarization which induces burst firing in immature type B cells appeared as early as P5, indicating that the $\mathrm{Ca}^{2+}$-activated $\mathrm{K}^{+}$current is one of the first conductances to regulate the intrinsic rhythmicity and excitability of these neurons during early postnatal life.

In addition to the contribution of sustained $\mathrm{K}^{+}$currents to the distinct firing pattern of central vestibular neurons, another cellular feature that regulates the resting activity of vestibular nuclear neurons is the activity of $\mathrm{N}$ methyl- $D$-asparate (NMDA) receptors [69, 70]. In particular, the discharge regularity of neurons in brain stem slices has been shown to be modulated by the activation of NMDA receptors [71], which operate more effectively in the early postnatal period than in adults [70,72]. Furthermore, developing neurons differed with respect to the time course of expression of NMDA receptor subunits [73]. This suggests that NMDA receptors may trigger the processes underlying the change in neuronal excitability during postnatal development.

The postnatal properties of canal-related vestibular nuclear neurons have been characterized in rats [74, 75]. During postnatal development, the resting discharge rate of neurons increased steadily from a very low and irregular firing pattern in neonates to reach a high and more regular state by the end of the first postnatal month. In very young rats $(\mathrm{P} 4)$, some cells displayed random bursts of spikes. The response sensitivity of these neurons to angular acceleration also matured progressively, reaching the adult level at the end of the first month $[74,75]$.

The properties of central otolith neurons in coding head movements near the horizontal plane have been studied in postnatal $[35,76-78]$ and adult rats $[77,79-$ 81]. With the use of such natural stimuli as off-vertical axis rotation (OVAR) [77, 78, 82-85] and horizontal linear acceleration [79-81], the best vectors of central otolith neurons of adult animals were found to point in all directions on the horizontal plane. Such a uniform spatial distribution was also observed in the cerebellar fastigial nucleus [82] and medial medullary reticular formation [86] of adult cats. However, an imbalance of spatial response patterns between the bilateral vestibular nuclei was observed following the restriction of otolith inputs by hemilabyrinthectomy $[87,88]$. This finding implies that in the normal state, where both labyrinths are intact, the crossed otolith signals serve to complement and supplement inputs arising from the ipsilateral otolith. During development, the contribution of the vestibular nuclei on both sides in coding head movements, however, is still unknown.

Recently, the development of vestibular nuclear neurons in coding head movements was studied in postnatal 
rats $[35,76,89]$. In these studies, OVAR was used to selectively stimulate the otolith by introducing a rotating gravity vector around the head [90]. All central otolith neurons displayed position-dependent changes in the firing rate during 360-degree OVAR, indicating their capability to code spatial information during low-frequency head movement [35]. However, the capacity of central otolith neurons to code head movements in neonatal rats is lower than the adult level. These neurons undergo progressive changes both in their resting discharge and spatiotemporal properties during postnatal development [89]. At P7, the vast majority of central otolith neurons showed irregular discharge patterns. As the rats matured, the overall population showed more regular patterns [35, 78]. Spontaneous activities of the neurons in the stationary position were analysed in relation to their response gains during otolith activation, and a positive correlation was observed from P14 onwards [35]. In rats older than $\mathrm{P} 14$, the best response orientation of central otolith neurons was found to point in all directions close to the horizontal plane, indicating that all head orientations on this plane were encoded within the vestibular nucleus [77, 78, 82]. At P7, however, central otolith neurons particularly tuned for the pitch response were not well developed. The vector orientations were found to distribute predominantly along the interaural axis (i.e. roll direction), indicating that the newborn rat's ability to code head positions with respect to gravity is more restricted than the adult's [76]. The mechanism underlying the temporal disparity in coding the roll and pitch information within the vestibular nucleus of postnatal rats remains to be resolved. However, it should be noted that the postnatal development of the spatial coding properties of central otolith neurons seems to be correlated with motor behaviour development. During postnatal development, lateral movement could be recorded at P2 [91]. Vertical movement was absent until $\mathrm{P} 9$, when the rats succeeded in turning their head upward in response to passive downward tilting [92]. This reaction was shown to be mature in the middle of the second postnatal week $[92,93]$. By P14, vertical movement of the whole body was observed and the animals were able to sit on their hind legs [36]. These features are chronologically matched with the emergence of pitch neurons within the lateral and descending vestibular nuclei during postnatal development [76].

It has been shown that otolith stimulation has a strong effect on systemic circulation and vagal activity [94]. Studies of the cardiovascular and respiratory response to vestibular stimulation in adult cats have demonstrated that tilts near the pitch plane are optimal for these reflexes
$[94,95]$. The absence of pitch information in central otolith neurons of young rats may imply the immaturity of the vestibulo-autonomic system.

In future studies, it would be of interest to correlate the morpho-electrophysiological features of central vestibular neurons with their projection patterns during the development of otolith function. This will enable us to unveil the maturation profile and functional connectivity among components of the central vestibular system.

\section{Development of Vestibulospinal and Vestibulo-Ocular Projections}

At early stages of embryonic development, vestibular nuclear neurons with specific axonal projection targets are localized to specific, segregated rhombomeric domains of the hindbrain neural tube in the chicken [96-98]. More recently, the two specific sets of vestibular neurons, namely the vestibulo-ocular and the vestibulospinal neurons, were identified in rhombomeres of embryonic chicks [99], frogs [59] and rats [100, 101]. These studies provide a ground-plan for elucidating the development of the connectivity patterns of the vestibular system [97].

At E11 in chicks, the vestibulo-ocular projection has a wider rostro-caudal distribution in the brain stem than the vestibulospinal projection [102]. The vestibular nuclear neurons are segregated according to their projection to either oculomotor or spinal cord targets, with minor overlap. Very few vestibular neurons project to both targets, as shown from injections of double fluorescent labels [102]. In chicks, the initial development of the dual projections in the secondary vestibular neurons may therefore occur later than E11 [102]. The development of such a dual projection pattern in the vestibular nuclei of postnatal mammalian species is still unexplored. The dual projections of secondary vestibular axons in the medial longitudinal fasciculus to extra-ocular motor nuclei and the spinal cord have been described, however, in adult squirrel monkeys [103].

\section{Vestibulospinal Pathways}

Vestibular signals are relayed to spinal motor centres via the lateral vestibulospinal tract (LVST) and medial vestibulospinal tract (MVST) [104]. The MVST originates primarily in the medial nucleus, joins the medial longitudinal fasciculus and projects bilaterally and monosynaptically to motoneurons in spinal lamina 7 throughout the cervical and upper thoracic levels. Through the MVST, the semicircular canal nerve has both excitatory and inhibitory disynaptic connections with the neck motoneurons [105-107]. Some of the utricular nerve-acti- 
vated vestibulospinal neurons also project through the MVST, and their axons terminate mainly in the upper cervical segments [108]. Several experiments also showed that the saccular projection to neck extensor motoneurons was mainly via the MVST [109-111].

The LVST, originating primarily in the lateral vestibular nucleus and the rostral part of the spinal vestibular nucleus, descends in the ventral part of the ventral funiculus to lumbar levels and terminates in spinal laminae 7 and 8 of the ventral horn $[112,113]$. About $73 \%$ of the utricular-activated vestibulospinal neurons project through the ipsilateral LVST and reach the cervico-thoracic junction and the lumbar spinal cord [108]. Moreover, $30 \%$ of saccular-activated vestibulospinal neurons send axons through the ipsilateral LVST to the upper cervical spinal cord [110], and disynaptically to the extensor neck motoneurons [111]. The semicircular canal nerve makes inhibitory trisynaptic connections with some neck motoneurons through the LVST $[114,115]$. In addition, the caudal parts of the medial and spinal vestibular nuclei give rise to a third vestibulospinal projection, the caudal vestibulospinal tract [116]. The function of this pathway, which appears to project bilaterally to all levels of the spinal cord, is still unclear. However, it has been reported that about $7 \%$ of the saccular nerve-activated vestibulospinal neurons project through the caudal vestibulospinal tract and terminate in the upper cervical segments [110].

Studies performed on E11 chicks demonstrated the development of two major longitudinal pathways from the vestibular nuclei to the upper cervical spinal cord, namely the MVST and the LVST [97, 98, 117]. At the embryonic stage, the contralaterally projecting vestibulospinal neurons in the MVST are localized largely to rhombomere 5 but with a substantial component in the lateral portion of rhombomere 4 [99]. The ipsilateral MVST group, however, is localized to rhombomere 6, with a minor spillover [99]. In both chick and rodent embryos, the cell bodies of the ipsilateral LVST are clustered in a region corresponding to rhombomere 4 , with a minor spillover into rhombomeres 3 or $5[101,118]$.

During development, the vestibulospinal neurons send their axons to the LVST and MVST, which have been segregated into various segments of the spinal cord both anatomically and physiologically [119-122]. In addition, the vestibulospinal neurons can be distinguished by their genetic characteristics [123]. In brief, the genesis of the vestibulospinal neurons occurs firstly in the lateral vestibular nucleus at E12 in the rat, then in the descending vestibular nucleus at E12-E13 and finally in the medial vestibular nucleus at E13-E14. Cells of the MVST remain proliferative at E12-E14, and neurons show great diversity in their projection targets and fibre courses [123]. In contrast, cells of the LVST are proliferative only at E12, and neurons are more uniform in their projections [124, 125]. The time of ingrowth of vestibulospinal axons into the spinal cord has also been studied in various species. In Xenopus laevis, there is a rostro-caudal gradient such that more caudally situated cells project their axons sooner to the spinal cord [126]. In zebra fish [127] and rats [36], however, laterally placed large neurons project their axons earlier than the small, medial neurons.

After birth, the vestibulospinal pathways continue to develop. In rats, $50 \%$ of the total LVST axons originating in the lateral vestibular nucleus are present on P2 and $88 \%$ of them reach the lumbar enlargement by P15 [36]. This finding is in agreement with the developmental projection of the vestibulospinal neurons to the cervical and lumbosacral cord segments in neonatal rats [128-130]. In addition, Clarac et al. [36] indicated that the development of the vestibular afferents and descending pathways in the first 2 postnatal weeks is essential to the maturation of the postural and locomotor functions.

\section{Development of the Vestibulospinal Reflex}

The head-turning response (cephalic response) to angular accelerations in the horizontal plane has been studied in postnatal rats [131]. This response, generated by the stimulation of the horizontal semicircular canals, increases gradually from the first to the seventh day of postnatal life without any visual influence [131].

In rats, the head-turning response appears earlier than the air-righting reflex, which is provoked by linear acceleration acting on the macular receptors [132, 133]. During postnatal development, it has been shown that the airrighting reflex does not appear until about P6-P7 [36, $134,135]$ and is not complete until about P14-P16 [132]. The air-righting response is not a simple reflex, as it involves not only maturation of the peripheral and central vestibular systems but also the capability of the motor system to organize the behavioural response [132, 136]. Airrighting can only be viewed as a demonstration of purely vestibular righting in the absence of tactile influence [137] in species that do not use vision to trigger righting, e.g. the rat [138]. The mouse, rat and rabbit show a similar time course of maturation of the righting reflex. The righting reflex in the rabbit, for example, appears at P3, develops rapidly between $\mathrm{P} 7$ and $\mathrm{P} 11$ and reaches the adult level by P15 [139].
66

Neuroembryology 2002;1:61-71
Lai/Chan 


\section{Vestibulo-Ocular Pathways}

In humans and other vertebrates, many vestibular nuclear neurons project to the extraocular motor nuclei [51-53], largely via the medial longitudinal fasciculus [48]. These vestibulo-ocular pathways [140, 141] provide a close link between the hair cells on the semicircular canal and the extra-ocular muscles for the generation of compensatory eye movements [142]. When compared with the wealth of information about the projections from the semicircular canal to extra-ocular motoneurons, only a few studies have described the pathways of otolith-ocular reflexes [143-147]. With regard to utriculo-ocular reflex arcs, Imagawa et al. [144] and Uchino et al. [146] demonstrated disynaptic connections between utricular primary afferents and ipsilateral abducens nucleus neurons. In addition, polysynaptic connections from the utricular afferents to contralateral trochlear motoneurons has been reported [145]. By means of intracellular recording, Uchino et al. [147] demonstrated the presence of polysynaptic long latency connections between the utricular nerve and motoneurons innervating superior and inferior oblique muscles. In the sacculo-ocular pathway, only 3\% of the saccular-activated vestibular neurons studied had direct ascending branches to the oculomotor nucleus [110]. Uchino et al. [111] suggested that saccular afferents seem to have polysynaptic linkages to extra-ocular motoneurons.

In larval frogs, retrograde labelling of the medial longitudinal fasciculus just caudal to the midbrain oculomotor complex revealed several subgroups of vestibular neurons that correspond to distinct adult vestibular nuclei [59]. The superior vestibular nucleus is the only source of bilateral oculomotor and trochlear projections in the rostral hindbrain. Vestibular neurons within the lateral and descending nuclei send fibres either ipsilaterally or contralaterally to the oculomotor complex [59]. In larval frogs, midbrain-projecting cells within the superior vestibular nucleus are clustered in a rhombomeric region corresponding to ipsi- and contralateral rhombomere $1 / 2$ [59]. In chick embryos, rhombomeres 1 and 2 both contribute bilaterally to the pool of midbrain-projecting cells within the superior vestibular nucleus [99, 148]. However, the ipsilateral ascending projections from rhombomere 3 in chicks [99], goldfish and zebra fish [149] represent an homologous rostral portion of the lateral vestibular nucleus. The ipsilateral oculomotor-projecting cell clusters in rhombomere 5 are comparable to a population of rostral descending vestibular nuclear neurons in adult chicks [150] or to neurons in the tangential nucleus in pigeons [151]. The contralaterally projecting neurons in rhom- bomeres 6-8 project to the trochlear and rostral oculomotor nuclei [152].

\section{Development of the Vestibulo-Ocular Reflex}

In the newborn kitten, stimulation of the ipsilateral vestibular nerve has been shown to evoke monosynaptic excitatory postsynaptic potentials and disynaptic inhibitory postsynaptic potentials in abducens motoneurons, while stimulation of the contralateral vestibular nerve produced disynaptic excitatory postsynaptic potentials [153], indicating that the basic vestibulo-ocular neuronal pathway is functional at birth. Moreover, high-frequency electrical stimulation of the vestibular nerve can elicit conjugate eye movements even in newborn rats [154], showing that the more central components of the vestibulo-ocular pathway are mature enough to be activated. However, it is not known whether natural stimulation of the vestibular receptor (i.e. rotation of the head) is able to elicit the vestibulo-ocular reflex (VOR) in newborn rats [154]. In rats [154], kittens [155] and rabbits [156], vision is not essential for the development of the VOR. The VOR can be elicited in rats well before their eyes open (15 days after birth) [154], and visual deprivation also has no effect on the maturation of the VOR. However, it seems that vision is necessary to achieve perfect compensatory eye movements over a wide frequency range of optokinetic stimulation [156].

These results show that the VOR can be activated in newborn animals immediately after birth. The decrease in threshold in eliciting the VOR during postnatal growth [154] is closely paralleled by changes in the dynamic characteristics of primary $[42,43]$ and central canal neurons [74]. In addition, it should be noted that only a few studies have reported the development of the otolith-ocular reflex in neonatal rats. It is still unknown whether the progressive change in properties of otolith-related vestibular nuclear neurons during the first 3 postnatal weeks contributes to the development of the otolith-ocular reflex [35]. Tegetmeyer [157] demonstrated that in conscious rabbits (P3), however, the eye muscles are capable of responding to static tilt stimulation for the stabilization of gaze.

In humans, the vestibular system is anatomically mature by the 5th month of gestation [11]. However, the VOR in children is quantitatively different from that in adults [158-160]. There is a marked modification of the VOR throughout childhood [for a review, see ref. 161]. In response to angular acceleration, for instance, newborn infants show distinct nystagmus, characterized by alternating slow and fast components, and reach the adult level after the first few months of life [161, 162]. An interest- 
ing phenomenon is that in children, the canal-ocular reflex and otolith-ocular reflex, elicited by vertical axis rotation and OVAR, respectively, develop independently of each other [160]. The canal-ocular reflex parameters (i.e. the time constant and the highest initial slow phase velocity) remain unchanged after birth, while the otolithocular reflex parameters (i.e. the amplitude of the modulation and the bias of the slow phase velocity) change with age, especially at the stage when children are learning to walk [160]. This finding implies that in children, the ability to walk is paralleled by a change in the otolith but not the canal response.

\section{Conclusion}

In comparison to other sensory systems, developmental studies of the vestibular system are relatively scarce. Exhaustive studies of the peripheral vestibular sys- tem are required to determine the functional significance of electrophysiological features in developing vestibular neurons and to correlate these with the structural and biochemical changes within the cell itself and within the terminal field of the hair cells. Further experiments are needed in the central vestibular system to clarify the pattern of vestibular circuitry by identifying afferent and efferent connections and their time of synaptogenesis. Also, experiments should be designed to correlate the morphology of growing neurons with their membrane and synaptic properties as they develop into mature entities. These are crucial for understanding how vestibular information is established in the brain during development.

\section{Acknowledgement}

This study was supported by research grants from the Hong Kong Research Grants Council to Y.S.C.

\section{References}

1 Zheng JL, Gao WQ: Analysis of rat vestibular hair cell development and regeneration using calretinin as an early marker. J Neurosci 1997 ; 17:8270-8282.

2 Dechesne CJ, Mbiene P, Sans A: Postnatal development of vestibular receptor surfaces in the rat. Acta Otolaryngol 1986;101:11-18.

3 Desmadryl G, Sans A: Afferent innervation patterns in crista ampullaris of the mouse during ontogenesis. Brain Res Dev Brain Res 1990;52:183-189.

4 Lysakowski A: Development of synaptic innervation in the rodent utricle. Ann NY Acad Sci 1999;871:422-425.

5 Mbiene JP, Sans A: Differentiation and maturation of the sensory hair bundles in the fetal and postnatal vestibular receptors of mouse: A scanning electron microscopic study. J Comp Neurol 1986;254:271-278.

6 Nordemar H: Postnatal development of the vestibular sensory epithelium in the mouse. Acta Otolaryngol 1983;95:447-456.

7 Nordemar H: Embryogenesis of the inner ear. II. The late differentiation of the mammalian crista ampullaris in vivo and in vitro. Acta Otolaryngol 1983;96:1-8.

8 Rusch A, Lysakowski A, Eatock RA: Postnatal development of type I and type II hair cells in the mouse utricle: Acquisition of voltage-gated conductances and differentiated morphology. J Neurosci 1998;18:7487-7501.

9 Sans A, Scarfone E: Afferent calyces and type I hair cells during development. A new morphofunctional hypothesis. Ann NY Acad Sci 1996; 781:1-12.
10 Anniko M, Nordemar H, Sobin A: Principles in embryonic development and differentiation of vestibular hair cells. Otolaryngol Head Neck Surg 1983;91:540-549.

11 Dechesne CJ: The development of vestibular sensory organs in human; in Romand R (ed): Development of Auditory and Vestibular Systems 2. Amsterdam, Elsevier, 1992, pp 419447.

12 Mbiene JP, Favre D, Sans A: The pattern of ciliary development in fetal mouse vestibular receptors. Anat Embryol (Berl) 1984;170:229238.

13 Mbiene JP, Favre D, Sans A: Early innervation and differentiation of hair cells in the vestibular epithelia of mouse embryo: SEM and TEM study. Anat Embryol (Berl) 1988;177:331-340.

14 Ruben RJ: Development of the inner ear of the mouse: A radioautographic study of terminal mitoses. Acta Otolaryngol 1967;(suppl 220):144.

15 Lysakowski A, Goldberg JM: A regional ultrastructural analysis of the cellular and synaptic architecture in the chinchilla cristae ampullares. J Comp Neurol 1997;389:419-443.

16 Lapeyre PNM, Guilhaume A, Cazals Y: Differences in hair bundles associated with type I and type II vestibular hair cells of the guinea pig saccule. Acta Otolaryngol 1992;112:635-642.

17 Peterson EH, Cotton JR, Grant JW: Structural variation in ciliary bundles of the posterior semicircular canal. Quantitative anatomy and computational analysis. Ann NY Acad Sci 1996;781:85-102.

18 Eatock RA, Chen WY, Saeki M: Potassium currents in mammalian vestibular hair cells. Sens Syst 1994;1:21-28.
19 Rennie KJ, Correia MJ: Potassium currents in mammalian and avian isolated type I semicircular canal hair cells. J Neurophysiol 1994;71: 317-329.

20 Ricci AJ, Rennie KJ, Correia MJ: The delayed rectifier, $\mathrm{I}_{\mathrm{kI}}$, is the major conductance in type I vestibular hair cells across vestibular end organs. Pflügers Arch 1996;432:34-42.

21 Rusch A, Eatock RA: A delayed rectifier conductance in type I hair cells of the mouse utricle. J Neurophysiol 1996;76:995-1004.

22 Sans A, Chat M: Analysis of temporal and spatial patterns of rat vestibular hair cell differentiation by tritiated thymidine radioautography. J Comp Neurol 1982;206:1-8.

23 Dechesne CJ, Rabejac D, Desmadryl G: Development of calretinin immunoreactivity in the mouse inner ear. J Comp Neurol 1994;346: 517-529.

24 Dechesne CJ, Lavigne-Rebillard M, Brehier A, Thomasset M, Sans A: Appearance and distribution of neuron-specific enolase and calbindin (CaBP $28 \mathrm{kDa})$ in the developing human inner ear. Brain Res 1988;469:221-230.

25 Dechesne CJ, Sans A, Keller A: Onset and development of neuron-specific enolase immune reactivity in the peripheral vestibular system of the mouse. Neurosci Lett 1985;61: 299-304.

26 Dechesne CJ, Thomasset M: Calbindin (CaBP $28 \mathrm{k}$ Da) appearance and distribution during development of the mouse inner ear. Brain Res 1988;468:233-242.

27 Van de Water TR, Anniko M, Nordemar H, Wersäll J: Development of the sensory receptor cells in the utricular macula. Acta Otolaryngol 1978;87:297-305. 
28 Anniko M: Development of the vestibular system; in Coleman JR (ed): Development of Sensory Systems in Mammals. New York, Wiley, 1990, pp 341-400.

29 Dememes D, Broca C: Calcitonin gene-related peptide immunoreactivity in the rat efferent vestibular system during development. Brain Res Dev Brain Res 1998;108:59-67.

30 Dememes D, Seoane A, Venteo S, Desmadry $\mathrm{G}$ : Efferent function of vestibular afferent endings? Similar localization of N-type calcium channels, synaptic vesicle and synaptic membrane-associated proteins. Neuroscience 2000 ; 98:377-384.

31 Dememes D, Dechesne CJ, Venteo S, Gaven F, Raymond J: Development of the rat efferent vestibular system on the ground and in microgravity. Brain Res Dev Brain Res 2001;128: 35-44.

32 Boyle R, Highstein SM: Efferent vestibular system in the toadfish: Action upon horizontal semicircular canal afferents. J Neurosci 1990; 10:1570-1582.

33 Brichta AM, Goldberg JM: Afferent and efferent responses from morphological fiber classes in the turtle posterior crista. Ann NY Acad Sci 1996;781:183-195.

34 Goldberg JM, Fernandez C: Efferent vestibular system in the squirrel monkey: Anatomical location and influence on afferent activity. $\mathrm{J}$ Neurophysiol 1980;43:986-1025.

35 Lai CH, Chan YS: Spontaneous discharge and response characteristics of central otolith neurons of rats during postnatal development. Neuroscience 2001;103:275-288.

36 Clarac F, Vinay L, Cazalets JR, Fady JC, Jamon M: Role of gravity in the development of posture and locomotion in the neonatal rat. Brain Res Brain Res Rev 1998;28:35-43.

37 Baird RA, Desmadryl G, Fernández C, Goldberg JM: The vestibular nerve of the chinchilla. II. Relation between afferent response properties and peripheral innervation patterns in the semicircular canals. J Neurophysiol 1988;60: 182-203.

38 Goldberg JM, Desmadryl G, Baird RA, Fernandez C: The vestibular nerve of the chinchilla. V. Relation between afferent discharge properties and peripheral innervation patterns in the utricular macula. J Neurophysiol 1990 63:791-804.

39 Desmadryl G, Raymond J, Sans A: In vitro electrophysiological study of spontaneous activity in neonatal mouse vestibular ganglion neurons during development. Brain Res 1986; 390:133-136.

40 Fernandez C, Baird RA, Goldberg JM: The vestibular nerve of the chinchilla. I. Peripheral innervation patterns in the horizontal and superior semicircular canals. J Neurophysiol 1988;60:176-181.

41 Curthoys IS: Firing rate measurement. Electroencephalogr Clin Neurophysiol 1978;45: 793-794.

42 Curthoys IS: The development of function of horizontal semicircular canal primary neurons in the rat. Brain Res 1979;167:41-52.
43 Curthoys IS: Postnatal developmental changes in the response of rat primary horizontal semicircular canal neurons to sinusoidal angular accelerations. Exp Brain Res 1982;47:295300.

44 Curthoys IS: The development of function of primary vestibular neurons; in Romand R (ed): Development of Auditory and Vestibular Systems. New York, Academic, 1983, pp 425461.

45 Romand R, Dauzat M: Modification of spontaneous activity in primary vestibular neurons during development in the cat. Exp Brain Res 1982;45:265-268.

46 Desmadryl G: Postnatal developmental changes in the response of mouse primary vestibular neurons to externally applied galvanic currents. Brain Res Dev Brain Res 1991;64: 137-143.

47 Zhang YK: Functional Development of Otolith Afferents in Postnatal Rats; PhD thesis, Hong Kong, 2001.

48 Brodal A, Pompeiano O: The vestibular nuclei in the cat. J Anat 1957;91:438-444.

49 Wilson VJ, Jones GM: Mammalian Vestibular Physiology. New York, Plenum, 1979.

50 Gacek RR: The course and central termination of first order neurons supplying vestibular end organs in the cat. Acta Otolaryngol Suppl 1969; 254:1-66.

51 Highstein SM, McCrea RA: The anatomy of the vestibular nuclei; in Buttner-Ennever JA (ed): Neuroanatomy of the Oculomotor System. Amsterdam, Elsevier, 1988, pp 177-202.

52 Buttner-Ennever JA: Patterns of connectivity in the vestibular nuclei. Ann NY Acad Sci 1992;656:363-378.

53 Buttner-Ennever JA: A review of otolith pathways to brainstem and cerebellum. Ann NY Acad Sci 1999;871:51-64.

54 Gilland E, Baker R: Conservation of neuroepithelial and mesodermal segments in the embryonic vertebrate head. Acta Anat (Basel) 1993; 148:110-123.

55 Lumsden A: The cellular basis of segmentation in the developing hindbrain. Trends Neurosci 1990;13:329-335.

56 Vaage S: The segmentation of the primitive neural tube in chicken embryos (Gallus domesticus). Adv Anat Embryol Cell Biol 1969;41:188.

57 Kuruvilla A, Sitko S, Schwartz IR, Honrubia V: Central projections of primary vestibular fibers in the bullfrog. I. The vestibular nuclei. Laryngoscope 1985;95:692-707.

58 Matesz C, Birinyi A, Straka H, Dieringer N: Location of dye-coupled second order canal and otolith neurons and of efferent vestibular neurons in the frog. Neurobiology 1998;6:226227.

59 Straka H, Baker R, Gilland E: Rhombomeric organization of vestibular pathways in larval frogs. J Comp Neurol 2001;437:42-55.

60 Altman J, Bayer SA: Development of the brain stem in the rat. III. Thymidine-radiographic study of the time of origin of neurons of the vestibular and auditory nuclei of the upper medulla. J Comp Neurol 1980;194:877-904.
61 Karhunen E: Postnatal development of the lateral vestibular nucleus (Deiters' nucleus) of the rat. Acta Otolaryngol Suppl 1973;313:1-87.

62 Morris RJ, Beech JN, Heizmann CW: Two distinct phases and mechanisms of axonal growth shown by primary vestibular fibres in the brain, demonstrated by parvalbumin immunohistochemistry. Neuroscience 1988;27:571596.

63 Fujii M, Goto N, Onagi S, Okada A, Kida A: Development of the human lateral vestibular nucleus: A morphometric evaluation. Early Hum Dev 1997;48:23-33.

64 Johnston AR, MacLeod NK, Dutia MB: Ionic conductances contributing to spike repolarization and after-potentials in rat medial vestibular nucleus neurons. J Physiol 1994;481:6177.

65 du Lac S, Lisberger SG: Membrane and firing properties of avian medial vestibular nucleus neurons in vitro. J Comp Physiol 1995;176: 641-651.

66 Dutia MB, Johnston AR: Development of action potentials and apamin-sensitive after-potentials in mouse vestibular nucleus neurones. Exp Brain Res 1998;118:148-154.

67 Lin Y, Carpenter DO: Medial vestibular neurons are endogenous pacemakers whose discharge is modulated by neurotransmitters. Cell Mol Neurobiol 1993;13:601-610.

68 Murphy GJ, du Lac S: Postnatal development of spike generation in rat medial vestibular nucleus neurons. J Neurophysiol 2001;85: 1899-1906.

69 Kinney GA, Peterson BW, Slater NT: The synaptic activation of $N$-methyl-D-aspartate receptors in the rat medial vestibular nucleus. $\mathrm{J}$ Neurophysiol 1994;72:1588-1595.

70 Takahashi Y, Tsumoto T, Kubo T: $N$-MethylD-aspartate receptors contribute to afferent synaptic transmission in the medial vestibular nucleus of young rats. Brain Res 1994;659: 287-291.

71 Yen JC, Chan SH: Interchangeable discharge patterns of neurons in caudal nucleus tractus solitarii in rat slices: Role of GABA and NMDA. J Physiol 1997;504:611-627.

72 Tsumoto T, Hagihara K, Sato H, Hata Y: NMDA receptors in the visual cortex of young kittens are more effective than those of adult cats. Nature 1987;327:513-514.

73 Wenzel W, Fritschy JM, Mohler H, Benke D: NMDA receptor heterogeneity during postnatal development of the rat brain: Differential expression of the NR2A, NR2B, and NR2C subunit proteins. J Neurochem 1997;68:469478.

74 Lannou J, Precht W, Cazin C: The postnatal development of functional properties of central vestibular neurons in the rat. Brain Res 1979; 175:219-232.

75 Lannou J, Cazin L, Hamann KF: Responses of central vestibular neurons to horizontal linear acceleration in the rat. Pflügers Arch 1980;385: 123-129.

76 Lai CH: Postnatal Development of Otolith Neurons in the Vestibular Nucleus of Rats; PhD thesis, Hong Kong, 1999. 
77 Lai CH, Chan YS: Properties of otolith-related vestibular nuclear neurons in response to bidirectional off-vertical axis rotation of the rat. Brain Res 1995;693:39-50.

78 Lai CH, Chan YS: Spontaneous activity of otolith-related vestibular nuclear neurons in the decrerebrate rat. Brain Res 1996;739:322329 .

79 Angelaki DE, Dickman JD: Spatiotemporal processing of linear acceleration: Primary afferent and central vestibular neuron responses. J Neurophysiol 2000;84:21113-2132.

80 Angelaki DE, Bush GA, Perachio AA: Twodimensional spatiotemporal coding of linear acceleration in vestibular nuclei neurons. J Neurosci 1993;13:1403-1417.

81 Bush GA, Perachio AA, Angelaki DE: Encoding of head acceleration in vestibular neurons. I. Spatiotemporal response properties to linear acceleration. J Neurophysiol 1993;69:2039_ 2055.

82 Chan YS, Cheung YM, Hwang JC: Effect of tilt on the response of neuronal activity within the cat vestibular nuclei during slow and constant velocity rotation. Brain Res 1985;345:271278.

83 Chan YS, Cheung YM, Hwang JC: Response characteristics of neurons in the cat vestibular nuclei during slow and constant velocity offvertical axes rotations in the clockwise and counterclockwise directions. Brain Res 1987; 406:294-301.

84 Chan YS, Cheung YM, Hwang JC: Unit responses to bidirectional off-vertical axes rotations in central vestibular and cerebellar fastigial nuclei. Prog Brain Res 1988;76:67-75.

85 Reisine H, Raphan T: Neural basis for eye velocity generation in the vestibular nuclei of alert monkeys during off-vertical axis rotation. Exp Brain Res 1992;92:209-226.

86 Chan YS, Chen CW, Lai $\mathrm{CH}$ : Response of medial medullary reticular neurons to otolith stimulation during bidirectional off-vertical axis rotation of the cat. Brain Res 1996;732. 159-168.

87 Chan YS: The coding of head orientations in neurons of bilateral vestibular nuclei of cats after unilateral labyrinthectomy: Response to off-vertical axis rotation. Exp Brain Res 1997. 114:293-303.

88 Chan YS, Shum DKY, Lai CH: Neuronal response sensitivity to bidirectional off-vertical axis rotations: A dimension of imbalance in the lateral vestibular nuclei of cats after unilateral labyrinthectomy. Neuroscience 1999;94:831843.

89 Lai CH, Chan YS: Postnatal development of resting discharge of otolith neurons in rat vestibular nucleus; in Claussen CF, Haid CT, Hofferberth B (eds): Equilibrium Research, Clinical Equilibriometry and Modern Treatment. Amsterdam, Elsevier, 2000, pp 17-21.

90 Cohen B, Suzuki JI, Raphan T: Role of the otolith organs in generation of horizontal nystagmus: Effects of selective labyrinthine lesions. Brain Res 1983;276:159-164.

91 Geisler HC, Westerga A, Gramsbergen A: Development of posture in the rat. Acta Neurobiol Exp (Warsz) 1993;53:517-523.
92 Petrosini L, Molinari M, Gremoli T: Hemicerebellectomy and motor behaviour in rats. I. Development of motor function after neonatal lesion. Exp Brain Res 1990;82:472482.

93 Brocard F, Vinay L, Clarac F: Development of hindlimb postural control during the first postnatal week in the rat. Brain Res Dev Brain Res 1999;117:81-89.

94 Yates BJ, Miller AD: Properties of sympathetic reflexes elicited by natural vestibular stimulation: Implications for cardiovascular control. J Neurophysiol 1994;71:2087-2092.

95 Rossiter CD, Hayden NL, Stocker SD, Yates BJ: Changes in outflow to respiratory pump muscles produced by natural vestibular stimulation. J Neurophysiol 1996;76:3274-3284.

96 Glover JC: Rhombomeres and longitudinal boundaries in the chicken embryo subdivide vestibular neurons according to axonal pathway. Abstr Soc Neurosci 1989; 15:959.

97 Glover JC: The organization of vestibulo-ocular and vestibulospinal projections in the chicken embryo. Eur J Morphol 1994;32: 193-200.

98 Glover JC, Petursdottir G: Pathway specificity of reticulospinal and vestibulospinal projections in the 11-day chicken embryo. J Comp Neurol 1988;270:25-38.

99 Diaz C, Puelles L, Marin F, Glover JC: The relationship between rhombomeres and vestibular neuron populations as assessed in quail-chicken chimeras. Dev Biol 1998;202: 14-28.

100 Auclair F, Belanger MC, Marchand R: Ontogenetic study of early brain stem projections to the spinal cord in the rat. Brain Res Bull 1993;30:281-289.

101 Auclair F, Marchand R, Glover JC: Regional patterning of reticulospinal and vestibulospinal neurons in the hindbrain of mouse and rat embryos. J Comp Neurol 1999;411:288-300.

102 Petursdottir G: Vestibulo-ocular projections in the 11-day chicken embryo: Pathway specificity. J Comp Neurol 1990;297:283-297.

103 Minor LB, McCrea RA, Goldberg JM: Dual projections of secondary vestibular axons in the medial longitudinal fasciculus to extraocular motor nuclei and the spinal cord of the squirrel monkey. Exp Brain Res 1990;83:921.

104 Wilson VJ, Peterson BW: Vestibulospinal and reticulospinal systems; in Brooks VB (ed): Handbook of Physiology. Section I: The Nervous System; vol II: Motor Control. Bethesda, American Physiological Society, 1981, chapter 14.

105 Shinoda Y, Sugiuchi Y, Futami T, Ando N, Kawasaki $\mathrm{T}$ : Input patterns and pathways from the six semicircular canals to motoneurons of neck muscles. 1 . The multifidus muscle group. J Neurophysiol 1994;72:26912702 .

106 Uchino Y, Isu N: Properties of vestibulo-ocular and/or vestibulocollic neurons in the cat; in Berthoz A, Graf W, Vidal PP (eds): The Head-Neck Sensory Motor System. New York, Oxford University Press, 1992, pp 266-272.
107 Wilson VJ, Maeda M: Connections between semicircular canals and neck motorneurons in the cat. J Neurophysiol 1974;37:346-357.

108 Sato H, Endo K, Ikegami H, Imagawa M, Sasaki M, Uchino Y: Properties of utricular nerve-activated vestibulospinal neurons in cats. Exp Brain Res 1996;112:197-202.

109 Sato H, Imagawa M, Sasaki M, Ikegami H, Uchino Y: Connections between the saccular nerve and neck extensor and flexor motoneurons in the decerebrate cat. Abstr Soc Neurosci 1994;20:1192.

110 Sato H, Imagawa M, Isu N, Uchino Y: Properties of saccular nerve-activated vestibulospinal neurons in cats. Exp Brain Res 1997; 116:381-388.

111 Uchino Y, Sato H, Sasaki M, Imagawa H, Ikegami H, Isu N, Graf W: Sacculocollic reflex arcs in cats. J Neurophysiol 1997;77:30033012.

112 Brodal A: Anatomy of the vestibular nuclei and their connections; in Kornhuber $\mathrm{HH}$ (ed): Handbook of Sensory Physiology. Berlin, Springer, 1974, vol 6/1, pp 239-352.

113 Holstege G, Kuypers HGJM: The anatomy of brainstem pathways to the spinal cord in cat: A labeled amino acid tracing study. Prog Brain Res 1982;57:145-175.

114 Bolton PS, Goto T, Wilson VJ: Horizontal canal input to upper cervical commissural neurons. Exp Brain Res 1993;92:549-552.

115 Sugiuchi Y, Izawa Y, Shinoda Y: Trisynaptic inhibition from the contralateral vertical semicircular canal nerves to neck motoneurons mediated by spinal commissural neurons. J Neurophysiol 1995;73:1973-1987.

116 Peterson BW, Maunz RA, Fukushima K: Properties of a new vestibulospinal projection, the caudal vestibulospinal tract. Exp Brain Res 1978;32:287-292.

117 Glover JC: Development of second-order vestibular projections in the chicken embryo. Ann NY Acad Sci 1996;781:13-20.

118 Glover JC: The development of brain stem projections to the spinal cord in the chicken embryo. Brain Res Bull 1993;30:265-271.

119 Carleton SC, Carpenter MB: Afferent and efferent connections of the medial, inferior and lateral vestibular nuclei in the cat and monkey. Brain Res 1983;278:29-51.

120 Holstege G: Brainstem-spinal cord projections in the cat, related to control of head and axial movement; in Buttner-Ennever JA (ed): Neuroanatomy of the Oculomotor System. Amsterdam, Elsevier, 1988, pp 431-469.

121 Peterson BW, Coulter JD: A new long spinal projection from the vestibular nuclei in the cat. Brain Res 1977;122:351-356.

122 Rapoport S, Susswein A, Uchino Y, Wilson VJ: Properties of vestibular neurones projecting to neck segments of the cat spinal cord. J Physiol 1977;268:493-510.

123 Kitao Y, Okoyama S, Moriizumi T, Kudo M Neurogenetical segregation of the vestibulospinal neurons in the rat. Brain Res 1993;620. 149-154. 
124 Bankoul S, Neuhuber WL: A direct projection from the medial vestibular nucleus to the cervical spinal dorsal horn of the rat, as demonstrated by anterograde and retrograde tracing. Anat Embryol (Berl) 1992;185:77-85.

125 Rose PK, Wainwright K, Neuber-Hess M Connections from the lateral vestibular nucleus to the upper cervical spinal cord of the cat: A study with the anterograde tracer PHAL. J Comp Neurol 1992;321:312-324.

126 Van Mier P, ten Donkelaar HJ: Early development of descending pathways from the brain stem to the spinal cord in Xenopus lae vis. Anat Embryol (Berl) 1984;170:295-306.

127 Mendelson B: Development of reticulospinal neurons of the zebrafish. II. Early axonal outgrowth and cell body position. J Comp Neurol 1986;251:172-184.

128 Kudo N, Furukawa F, Okado N: Development of descending fibers to the rat embryonic spinal cord. Neurosci Res 1993;16: 131-141.

129 Lakke E: The projections to the spinal cord of the rat during development: A timetable of descent. Adv Anat Embryol Cell Biol 1997; 135:1-143.

130 Leong SK, Shieh JY, Wong WC: Localizing spinal cord-projecting neurons in adult albino rats. J Comp Neurol 1984;228:1-17.

131 Parrad J, Cottereau P: Apparition des réactions rotatoires chez le rat nouveau-né. Physiol Behav 1977;18:1017-1020.

132 Hard E, Larsson K: Development of air righting in rats. Brain Behav Evol 1975;11:53-59.

133 Sans A, Pujol R, Marty R: Etude du réflexe de redressement dans la période postnatale chez divers mammifères. Psychol Fr 1968;13:351353.

134 Laouris Y, Kalli-Laouri J, Schwartze P: The postnatal development of the air-righting reaction in albino rats. Quantitative analysis of normal development and the effect of preventing neck-torso and torso-pelvis rotations. Behav Brain Res 1990;37:37-44.

135 Pellis SM, Pellis VC: Development of righting when falling from a bipedal standing posture: Evidence for the dissociation of dynamic and static righting reflexes in rats. Physiol Behav 1994;56:659-663.

136 Lannou J, Precht W, Cazin C: Functional development of the central vestibular system; in Romand R (ed): Development of Auditory and Vestibular Systems. New York, Academic, 1983, pp 463-478.
137 Monnier M: Functions of the nervous system; in Monnier M (ed): Motor and Psychomotor Functions 2. Amsterdam, Elsevier, 1970, pp 418-431.

138 Chen YC, Pellis SM, Sirkin DW, Potegal M, Teitelbaum P: Bandage backfall: Labyrinthine and non-labyrinthe components. Physiol Behav 1986;37:805-814.

139 Schonfelder J, Schwartze P: Development of the falling flip-over reflex in the ontogenesis of rabbits (in German). Acta Biol Med Ger 1970;25:109-114.

140 Ezure K, Graf W: A quantitative analysis of the spatial organization of the vestibulo-ocular reflexes in lateral- and frontal-eyed animals. II. Neuronal networks underlying vestibulo-oculomotor coordination. Neuroscience 1984;12:95-109.

141 McCrea RA, Strassman A, Highstein SM: Anatomical and physiological characteristics of vestibular neurons mediating the vertical vestibulo-ocular reflexes of the squirrel monkey. J Comp Neurol 1987;264:571-594.

142 Baker R, Mano N, Shimazu H: Postsynaptic potentials in abducens motoneurons induced by vestibular stimulation. Brain Res 1969;15: 577-580.

143 Chan YS, Hwang JC, Cheung YM: Vestibular function of saccule in cats as indicated by the response of Deiters' nucleus to static tilts. Exp Brain Res 1979;35:591-594.

144 Imagawa M, Isu N, Sasaki M, Endo K, Ikegami $\mathrm{H}$, Uchino $\mathrm{Y}$ : Axonal projections of utricular afferents to the vestibular nuclei and the abducens nucleus in cats. Neurosci Lett 1995;186:87-90.

145 Sasaki M, Hiranuma K, Isu N, Uchino Y: Is there a three neuron arc in the cat utriculotrochlear pathway? Exp Brain Res 1991;86: 421-425.

146 Uchino Y, Ikegami H, Sasaki M, Endo K, Imagawa M, Isu N: Monosynaptic and disynaptic connections in the utriculo-ocular reflex arc of the cat. J Neurophysiol 1994;71: 950-958.

147 Uchino Y, Sasaki M, Sato H, Imagawa H, Suwa H, Isu N: Utriculoocular reflex arc of the cat. J Neurophysiol 1996;76:1896-1903.

148 Marin F, Puelles L: Morphological fate of rhombomeres in quail/chick chimeras: A segmental analysis of hindbrain nuclei. Eur $\mathrm{J}$ Neurosci 1995;7:1714-1738.

149 Suwa H, Gilland E, Baker R: Segmental organization of vestibular and reticular projections to spinal and oculomotor nuclei in the zebrafish and goldfish. Biol Bull 1996;191: 257-259.
150 Labandeira-Garcia JL, Guerra-Seijas MJ, Labandeira-Garcia JA, Jorge-Barreiro FJ: Afferent connections of the oculomotor nucleus in the chick. J Comp Neurol 1989;282:523534.

151 Arends JJ, Allan RW, Zeigler HP: Organization of the cerebellum in the pigeon (Columba livia). III. Corticovestibular connections with eye and neck premotor areas. J Comp Neurol 1991;306:273-289.

152 Straka H, Gilland E, Baker R: Rhomobomeric pattern of hindbrain efferent neurons is retained in adult frogs. Abstr Soc Neurosci 2000;26:310.

153 Uchino Y, Hirai N: The vestibulo-ocular reflex arc in the newborn kitten. An electrophysiological investigation. Exp Brain Res 1983;53:29-35.

154 Curthoys IS: The vestibulo-ocular reflex in newborn rats. Acta Otolaryngol 1979;87:484489.

155 Flandrin TM, Courjon JH, Jeannerod M: Development of the vestibulo-ocular response in the kitten. Neurosci Lett 1979;12:295-299.

156 Collewijn H: Optokinetic and vestibulo-ocular reflexes in dark-reared rabbits. Exp Brain Res 1977;27:287-300.

157 Tegetmeyer H: Spatial orientation of extraocular muscle EMG responses to tilt in the rabbit during postnatal development. Exp Brain Res 1994;98:65-74.

158 Jongkees LBW, Gasthuis W: La fonction de l'organe vestibulaire du nouveau-né et de l'enfant. JFORL J Fr Otorhinolaryngol Audiophonol Chir Maxillofac 1973;22:97-101.

159 Ornitz EM, Kaplan AR, Westlake JR: Development of the vestibulo-ocular reflex from infancy to adulthood. Acta Otolaryngol 1985; 100:180-193.

160 Wiener-Vacher SR, Toupet F, Narcy P: Canal and otolith vestibulo-ocular reflexes to vertical and off vertical axis rotations in children learning to walk. Acta Otolaryngol 1996;116: 657-665.

161 Ornitz EM: Normal and pathological maturation of vestibular function in the human child; in Romand R (ed): Development of Auditory and Vestibular Systems. New York, Academic, 1983, pp 479-536.

162 Ornitz EM, Atwell DO, Hartmann EE, Kaplan AR: The maturation of vestibular nystagmus in infancy and childhood. Acta Otolaryngol 1979;88:244-256. 